JOANNA DZIONEK-KOZłOWSKA, KAMIL KOWALSKI, RAFAŁ MATERA

Department of History of Economic Thought and Economic History

of the Faculty of Economics and Sociology, University of Lodz

\title{
GEOGRAPHY MATTERS. ENVIRONMENTAL FACTORS THAT AFFECTED THE "TAKE-OFF" OF LODZ
}

Zarys treści: Niniejszy artykuł, na przykładzie analizy gospodarki miasta Łodzi, stanowi kolejny przyczynek w coraz obfitszej literaturze na temat czynników pobudzających wzrost gospodarczy. Autorzy pokazuja, w jaki sposób czynniki geograficzne moga stymulować bądź hamować rozwój gospodarczy w różnych okresach. W artykule omawiają przyczyny gospodarczej stagnacji miasta przez pierwsze cztery stulecia jego istnienia i następujacy po tym jego szybki rozwój. W toku badań ustalili przede wszystkim, że w przypadku Łodzi długofalowy rozwój nie byłby możliwy bez kilku czynników środowiskowych, które pozwoliły podjąć dobre decyzje i zapewniły miastu stabilność instytucjonalną.

The content outline: The paper contributes to a growing body of literature on factors triggering economic growth by providing an analysis of the case of city of Lodz. We demonstrate how geographical factors can play their roles as incentives or hindrances of economic development in different periods of time. The paper discusses the reasons for the city's economic stagnation for the four first centuries of its existence and the subsequent rapid growth. The main finding is that in the case of Lodz, the long-term development would not be possible without a few environmental factors which supported to make good decisions and to impose institutional stabilization of the city.

Słowa kluczowe: czynniki rozwoju, rozwój Łodzi, czynniki geograficzne, czynniki środowiskowe, czynniki instytucjonalne

Keywords: factors of development, development of Lodz, geographical factors, environmental factors, institutional factors 


\section{Theoretical background. Hypothesis of the paper}

The problems of the causes of economic success and factors of wealth have been the subject of investigation of researchers since the beginning of economics as a scientific discipline. Already the father of economics and economic history - Adam Smith - entitled his major economic treatise An Inquiry into the Nature and Causes of the Wealth of Nations (1776). Before the Marginal Revolution of the 1870s, the matter had been taken on by nearly all political economists, even by those who disagreed with the Smithian answer.

After World War II, with the increasing popularity of theories of economic growth, a growing group of scientists has been adopting a global perspective. Within the framework of development economics they have sought to explain the differences between the industrialized, capitalist states and the poor ones that have just entered the path of growth. Despite some changes in the dominant paradigm and shifts of emphasis taking place in subsequent decades, the question "What is the crucial for the development?" still remains on the short list of the most important themes of economic investigations.

Many new inspiring works devoted to the subject were issued at the turn of the third millennium. Amongst the authors analyzing the question were both economic historians (Robert Allen, Alan Beattie, Rondo Cameron, Gregory Clark, David Landes, Angus Maddison'1), leading economists (Daron Acemoglu, Douglass C. North, Mancur Olson, Deepak Lal, Amartya K. Sen, Joseph Stiglitz, Jeffrey Sachs²), and representatives

${ }^{1}$ R.C. Allen, Global Economic History. A Very Short Introduction, New York, 2011; A. Beattie, False Economy. A Surprising Economic History of the World, New York, 2009; R. Cameron, A Concise Economic History of the World. From Palaeolithic Times to the Present, Oxford, 1993; R. Cameron, L. Neal, Historia gospodarcza świata. Od paleolitu do czasów najnowszych, trans. by H. Lisicka-Michalska, M. Kluźnika, ed. $4^{\text {th }}$ rev., Warsaw, 2004; G. Clark, A Farewell to Alms. A Brief Economic History of the World, Princeton-Oxford, 2007; D. Landes, The Wealth and Poverty of Nations. Why Some Are So Rich and Some So Poor, New York, 1998; A. Maddison, Monitoring the World Economy 1820-1992, Paris, 2000; id., The World Economy. A Millennial Perspective, Paris, 2001; id., Contours of the World Economy 1-2030 AD. Essays in Macro-Economic History, Oxford, 2007; id., "Explaining the economic performance of nations 1820-1989", in: Convergence of Productivity, ed. by W. Baumol, R. Nelson, E. Wolff, Oxford, 1993, pp. 20-61.

2 D. Acemoglu, J.A. Robinson, Why Nations Fail. The Origins of Power, Prosperity and Poverty, New York, 2012; D. Acemoglu, S. Johnson, J.A. Robinson, "Institutions as the fundamental cause of long-run growth", in: Handbook of Economic Growth, vol. 1A, ed. by Ph. Aghion, S. Durlauf, North Holland, 2005; D. Acemoglu, J.A. Robinson, "The role of institutions in growth and development", in: The World Bank Commission on 
of other scientific disciplines, such as Paul Colinvaux (biologist), Jared Diamond (geographer) or James A. Robinson (political scientist). ${ }^{3}$

It is worth remembering once again that the global financial crisis which began in 2007/2008, apart from the disruptions in economies of most countries in the world, led to the impairment of the authority of economists, and to some extent to the impairment of the subject of economics itself. Academics and publicists heatedly discussed the reasons why, despite the continuous development of the theory of economics and the advancement of research methods applied by economists, once more they failed to prevent perturbation in the world economy. That is why such a crucial question as "How did individual countries, regions, cities and societies come to a state in which there are today?" appeared again in the mainstream of the economists' research.

A particularly influential voice on the factors stimulating development was especially that of Daron Acemoglu and James A. Robinson in their bestseller Why Nations Fail: The Origins of Power, Prosperity, and Poverty (2012). ${ }^{4}$ According to these authors, economic success is not just the result of geographical factors, such as location, territory, possession of water and other natural resources, nor the cultural perspective, religion or luck, but economic decisions affecting the activation of inclusive economic institutions which are an outcome of political choices. Indeed, the decisions of authorities have a huge impact on

Growth and Development, Working Paper no. 10, Washington, 2008; D. Acemoglu, Introduction to Modern Economic Growth, Princeton-Oxford, 2009; D. Lal, Reviving the Invisible Hand. The Case for Classical Liberalism in the Twenty-First Century, New Jersey, 2006; D.C. North, Structure and Change in Economic History, New York, 1981; id., Institutions, Institutional Change and Economic Performance, Cambridge, 1990; id., Understanding the Process of Economic Change, New Jersey, 2005; M. Olson, The Rise and Decline of Nations. Economic Growth, Stagflation, and Social Rigidities, New Haven-London, 1982; J. Sachs, The End of Poverty. The Economic Possibilities for Our Time, New York, 2005; A.K. Sen, Poverty and Famines. An Essay on Entitlement and Deprivation, Oxford, 1982; id., Development as Freedom, New York, 1999; J.E. Stiglitz, Globalization and its Discontents, New York, 2002; id., The Price of Inequality. How Today's Divided Society Endangers Our Future, New York, 2012.

${ }^{3}$ P. Colinvaux, The Fates of Nations. A Biological Theory of History, New York, 1980; J. Diamond, Guns, Germs and Steel. The Fates of Human Societies, New York, 1997; id., Collapse. How Societies Choose to Fail or Succeed, New York, 2005; D. Acemoglu, J.A. Robinson, Why Nations Fail...; J.A. Robinson, "Economic development and democracy", Annual Review of Political Science, 2006, no. 9, pp. 503-522.

4 The authors, using a number of historical examples, tried to explain the origins of differences between rich and poor countries. See more: R. Matera, "Studia nad bogactwem i ubóstwem narodów na przełomie mileniów - wkład Darona Acemoglu i Jamesa A. Robinsona", Ruch Prawniczy, Ekonomiczny i Socjologiczny, 76, 2014, no. 1 , pp. 269-282. 
establishing institutions which include new social groups involved in economic activity while removing institutions that exclude a part of society from these activities. ${ }^{5}$

Acemoglu and Robinson note that geographical factors may have been important, especially in times of the dominance of agriculture, but these factors do not explain either today's inequalities or the long-term economic stagnation of some nations. A critique of certain elements of Acemoglu and Robinson's approach has been provided with details by Dzionek-Kozłowska and Matera. ${ }^{6}$

Nonetheless, the question remains as to how it happened that one state or city could "take off" in one part of the world and why it turned out to be difficult or even impossible to launch "developing system" in different part of the globe. That question led to deeper searches into the institutional and environmental sides. The results of these searches are variations of the "geography hypothesis". The outcome of moving into the first direction was the religion/values/morals hypothesis. Its roots may be traced to some statements by classical economists (e.g., Adam Smith, John S. Mill); yet it seems in this case the far greater impact was exerted by the nineteenth-century's German philosophers who influenced social thinkers of the so-called German historical school of political economy. The latter point has been noticed by many modern scholars, and in contemporary economic literature it is frequently associated with and expressed by the notion of path dependence (e.g., D.C. North, A. Beattie). ${ }^{7}$ Agreeing with the concept's general tone, the path of a nation's socioeconomic development is then perceived as being deeply rooted in history and delineated by cultural factors.

${ }^{5}$ See more: J. Dzionek-Kozłowska, R. Matera, "New institutional economics' perspective on wealth and poverty of nations. Concise review and general remarks on Acemoglu and Robinson's concept", Scientific Annals of the 'Alexandru Ioan Cuza' University of Iasi. Economic Sciences, 2015, no. 62 (SI), pp. 11-18; iid., "O poszukiwaniu przyczyn bogactwa i nędzy narodów w teorii Darona Acemoglu i Jamesa A. Robinsona", Gospodarka Narodowa, 27, 2016, no. 5 (285), pp. 5-26.

${ }^{6}$ Iid., "Institutions without culture. A critique of Acemoglu and Robinson's theory of economic development", Lodz Economic Working Papers, 2016, no. 9, pp. 1-15.

7 The idea of path dependence was coined in the 1980s by Paul David and Brian Arthur who proposed it to explain technological progress and the process of bringing new products onto the market. Then the concept was relatively quickly used to analyse many other phenomena. It seems its implementation to economic development analysis occurred thanks to D.C. North. See: P. David, "Clio and the economics of QWERTY", American Economic Review, 75, 1985, no. 2, pp. 332-337; B. Arthur, "Competing technologies, increasing returns, and lock-in by historical small events", Economic Journal, 1989, no. 1, pp. 116-131; D.C. North, Institutions, Institutional Change... 
In recent decades, this line of reasoning and the importance of the informal, culture-embedded institutions have been underlined in the seminal works of D.C. North. His wide-ranging theory, which allowed for both the informal (culture-related) and formal constraints, should be regarded as a cornerstone of the last decades' revival of the institutional approach, both in theories of economic development and in models of economic growth.

After reading the works mentioned above, it can be concluded that there is no single leading explanation of the cause of development but one needs to indicate the importance of a wide variety of factors: geographical (which are connected with technological development reducing burdens of bad geography ${ }^{8}$ ); cultural (understood more as developing the skills of individuals in order to break down cultural barriers, which can be achieved by better education); institutional (including political and legal ones) as well as associated with the extraordinary "accidents of history" (e.g. a revolution or a sudden change of the government). It should be emphasized that most of the authors looked for various factors determining the causes of wealth and poverty, not trying to evaluate which of them had more or less impact on the level of economic development.

Besides simply highlighting elements regarded as the roots of development, creating a theory requires an explanation of the interrelations between mentioned factors. The complexity of the matter and the effort put into finding a solution have resulted in an overwhelming diversity of combinations difficult to fit in a rigid classification. It seems, however, that at the very general level, the existing concepts may be placed within a spectrum extending from the theories highlighting the role of environmental components to those highlighting the human factor. Human-related factors such as skills, abilities and elements of culture (in the widest sense of the term) are more changeable. In these cases, the most direct and unquestionable source of economic success is the technological knowledge of how to use the accessible resources.

Seen as broadly defined resources attainable by people in particular times and places, the environmental components constitute prerequisites for economic development. Two types are most often shown. The first one are geographic endowments, which are vital for agriculture (e.g. climate, availability of water, the harshness of the terrain, fertility of the soil, diversity of flora and fauna). And the second one are energy resources, with special attention devoted to coal, iron, and hydrocarbons,

\footnotetext{
8 The term released by Allen: id., op. cit., p. 14.
} 
although in the light of the type of industrial progress in the last three centuries, this is not surprising. As access to the environmental benefits/drawbacks is place-dependent, the explanations of this kind are commonly presented under the label "geography hypothesis".

The idea that the environment has a significant impact on human behaviour and, as such, wields an impact on people's wealth, has a longtime history. Some remarks in such a vein are presented in Geographica by Strabo, then expounded by such famous thinkers as Niccolò Machiavelli and Charles de Montesquieu, and they show up in the works by nineteenth-century historians, geographers, and biologists. ${ }^{9}$ One may cite the famous passage from Smith's Wealth of Nations devoted to the significance of having access to water basins or rivers as a prerequisite to enlarge the "extent of the market", which, in turn, deepens the division of labour and creates a foundation for economic growth. Indeed, having quicker, cheaper, and safer transport had been greatly appreciated years before, and its influence on the country's economic prosperity had been understood very well in the mercantilist era of protectionism as well.

Analysis of the significance of good location for economic development gained fresh impetus thanks to Alfred Marshall's introduction of the notion of the "industrial district" and his pointing to the positive externalities accessible to entities located within such an area. An illustration may be found in Marshall's Principles of Economics: "England's geographical position caused her to be peopled by the strongest members of the strongest races of northern Europe; a process of natural selection brought to her shores those members of each successive migratory wave who were most daring and self-reliant. Her climate is better adapted to sustain energy than any other in the northern hemisphere. She is divided by no high hills, and no part of her territory is more than twenty miles from navigable water, and thus there was no material hindrance to freedom of intercourse between her different parts". ${ }^{10}$

The above views need not only be applied at the state level; they are also relevant to understand the development of cities. In such a context, the following questions arise. Why did some municipal economies manage to succeed while the others failed? Can the economic prosperity of cities be viewed as a consequence of specific cultural or rather geographical patterns? New concepts of the role of geographical location

${ }^{9}$ D. Roller, The Geography of Strabo. An English Translation, with Introduction and Notes, Cambridge, 2014; N. Machiavelli, "Discourses on the first ten books of Titus Livius", in: The Historical, Political, and Diplomatic Writings of Niccolo Machiavelli, vol. 2, Boston, 1882; C.L. de Montesquieu, The Spirit of the Laws, Cambridge, 1989.

${ }^{10}$ A. Marshall, Principles of Economics, vol. 2, London, 1961, App. A, par. 10. 
often include not only the concentration of human actions in district or agglomeration, but they also indicate the appearance of new processes, less measurable. The role of external effects and technology in the new phases of development of the city or region are mostly underlined..$^{11}$

The object of our study is the history of Lodz Industrial District (as example of the region), Lodz (as example of the city) and brewery in Lodz (as example of the company). We claim this city's economic past gives an opportunity to indicate how geographical and institutional factors can interact and push forward economic development. We concentrate mainly on traditional geographical factors which are often neglected or even forgotten in the analysis about economic development of Lodz. We formulate the hypothesis that, in the case of Lodz, the long-term development would not be possible without a few environmental factors which helped make good decisions and introduce institutional stabilization of the city. In the last part of the article we focus on Karol Anstadt's brewery as good direct example of interaction between geographical and institutional connections. The brewery was deliberately founded nearby the Łódka River which decreased the cost of water supply and facilitated the brewing process. At the same time (1866), the consumption tax was repealed which resulted in boosting demand for broadly understood food products, including beer. Not only did the coincidence of these circumstances give uniqueness to and distinguished Lodz brewery market from others in the Kingdom of Poland (henceforth: KP), but it helped launch and run a successful business.

We use in the title of the paper Walt Rostow's expression of the takeoff, ${ }^{12}$ which means that we mainly focus on the moment of the economic (industrial) origin of the city of Lodz. We close our description with the beginning of the twentieth century.

\section{Decisive environmental factors that affected development of $\mathrm{Lodz}$}

The impact of the geographical factors on the development of Lodz is linked to the specificity of the history of this city whose development did not proceed gradually, but by booms and slumps, and was linked to both geographical determinants and political decisions. Metaphorically,

11 See more: M. Sokołowicz, Rozwój terytorialny w świetle dorobku ekonomii instytucjonalnej. Przestrzeń, bliskość, instytucje, Łódź, 2015, pp. 53-54.

${ }^{12}$ W. Rostow, The Stages of Economic Growth. A Non-Communist Manifesto, Cambridge, 1990, pp. 4-16. 
one might talk about two births of the city. The first one took place in 1423, when Lodz received the city charter thanks to King Władysław Jagiełło. The second one was in the 1820s and was linked with the decision of the authorities of the KP to designate Lodz as a new industrial centre. The geographical conditions - mainly the physical ones which determine natural resource endowments - did not alter, although their economic value did. They were rediscovered in a way, due to technical progress.

The city is situated in a physical region called the Lodz Upland, which is the most northern part of an upland area of southern Poland. ${ }^{13}$ The Upland falls from westwards, which results in a difference of altitude of about 100 metres within the contemporary borders of Lodz.

According to Polish agricultural land classification system class I identifies the most fertile soil which is easily cultivated while the VI - the weakest one lacking essential plant nutrients. Only $20 \%$ of the area of agricultural soil in Lodz was good or average to good (with the predominance of poor classes IV-VI). In the pre-industrial era, the soil was even worse because of the high groundwater level which made it over-humidified and acidified. It lacked drainage, liming and fertilization. Lodz was surrounded by large forests till the nineteenth century. In consequence, the city was not easily accessible. For almost four centuries, the migration of settlements in the region depended mainly on the natural conditions, e.g. quality of the soil, and shape of the ground. Because of the poor quality of soil and relative inaccessibility, the Lodz Upland was the last to be inhabited among the other valleys nearby, two of which were formed by rivers, the Pilica and the Vistula, and which take their names from these rivers, with the third called the Warsaw-Berlin Valley. ${ }^{14}$

Considering the time when the city received the municipal rights, one more specificity can be pointed out in its development. In the Middle Ages, cities were almost always located on big rivers, which it typical especially of those which later became the most influential urban centres. The same was also true in Poland, including the towns located in the vicinity of Lodz. Those were situated on the big rivers: the Warta and the Pilica, and the smaller ones, like the Bzura, the Ner, and the Prosna Rivers. That, however, was not the case with Lodz. By contrast,

${ }_{13}$ A Comparative Study of Eódż and Manchester. Geographies of European Cities in Transition, ed. by S. Liszewski, C. Young, Łódź, 1997, p. 12.

${ }^{14}$ J. Dylik, Rozwój osadnictwa w okolicach Łodzi, Łódź, 1948 (Acta Geographica Lodziensis, 2). 
this city was placed on the line of drainage basins. The terrain is situated on the watershed of the Vistula and the Odra Rivers, the two biggest rivers of Poland. The water parting goes right through the Lodz's district of Julianów. It should also be noticed that the city was crisscrossed by rivulets and brooks that flow into the tributaries of these rivers: the Łódka, the Bałutka, the Jasien, the Karolewka and the Olechówka were among them.

Furthermore, the Lodz region is relatively poor when it comes to raw materials. It has never been an asset the city relied on for its development. Some deep lignite resources were found in the valleys of both the Olechówka and the Karolewka. However, due to the small thickness, small spatial extent, and retention in built-up areas, they did not represent economic value. Some minor clay resources were heavily exploited in the nineteenth century for the building of factories (there were 35 points of clay exploitation in the second half of thecentury).

The opportunities of Lodz grew in 1815 after the creation of the KP resulting from the decisions made at the Congress of Vienna at the end of the Napoleonic wars. It meant that the Lodz region, which formerly belonged to the Prussian partition, became a part of the Polish Kingdom. Not surprisingly, those shifts of borders had not only political but also economic consequences. Some traditional trade connections were cut. As a result, the problems of the textile industry in Greater Poland and Silesia occurred, since those two regions remained in Prussia. Producers from there were cut off from their customers in other parts of the former Poland. Such decline in demand was difficult to compensate on the much more competitive Prussian internal market. On the other hand, the textile industry in the KP had not been developed well enough to quickly increase its capacity so as to benefit from the unsatisfied demand. Nevertheless, this opportunity to make profits had been noticed triggering a gradual influx of bankrupt weavers from Greater Poland and Silesia to the KP. Activities of the owners of landed estates who hoped that industrialisation would increase their income, encouraged immigration, yet Lodz was not a city with demographic or economic potential at that time.

In those circumstances, however, there were three factors in favour of Lodz as a place to settle, two of which had been physically present for centuries before. Acknowledged as geographical factors, they were access to soft and clean water from the unpolluted rivulets flowing through the city and surrounding area, and an abundance of wood and timber from the forests which had previously made the city difficult to access (in the early nineteenth century, forests and wetlands occupied 
$76 \%$ of the city area). Access to water was a necessary condition for the development of the textile industry. In the nineteenth century, the numerous streams flowing westwards from the Lodz Upland carried plenty of water, which permitted their use as sources of energy for mills. The streams provided high quality water necessary to produce woollen, linen and cotton cloth. This characteristic of the river system was by far the most important factor highlighted in the famous inspection by Stanisław Staszic in 1825, who noted that "Lodz, together with its vast region, is located on a huge and high hill with numerous springs". ${ }^{15}$ The availability of timber helped meet the construction demands for housing, thus, in the new phase of technological progress, those previously insignificant components of the city's environment became economic advantages.

The third factor was of the geographical-institutional character. While cities like Włocławek, Kalisz, Sieradz, Wielun and Częstochowa became border areas, Lodz was still situated in the centre of the KP and had enough distance to the nearest border in the West (a little more than $100 \mathrm{~km}$ ). It had a significant meaning, as all the investments made in the districts or border areas carried a risk connected with the changing of customs borders. Those advantages taken together crated a fertile background for Lodz's development, yet they were not enough to automatically bring fast progress and to explain the demographic explosion which took place in the subsequent decades.

The decisive moment for Lodz's history was in the beginning of the 1820s. Rajmund Rembielinski - chairman of the Commission of Mazovian Province - made a request to the Government Commission of Internal Affairs and Police to create a factory settlement in this city. In July 1820, he visited Ozorków, Aleksandrów, Zgierz, and Lodz, selecting this city as the future centre of the textile industry. After the inspection, Rembielinski prepared a report that listed the advantages of Lodz. These included: favourable ownership (proximity of vast governmental area near the city - so-called Wojtówka area), hydrographic conditions - the presence of numerous swift streams, easy wood supply, and convenient location near the main routes. ${ }^{16}$

Rembieliński's initiative brought about several crucial institutional decisions. Permission to settle a new factory district was given in 1821.

15 A Comparative Study of Łódź and Manchester..., p. 13.

16 "Trzy raporty Rajmunda Rembielińskiego, prezesa Komisji Województwa Mazowieckiego z objazdu łęczyckiego w roku 1820", Rocznik Oddziału Łódzkiego Towarzystwa Historycznego, 1, 1928, pp. 51-70. 
Between 1821 and 1823, under new spatial regulations, a clothing settlement (the so called New City - Nowe Miasto) was officially founded, while between 1824 and 1828 the cotton-linen settlement, with four colonies, was formed. The first industrial district was successfully established in 1824 (the linen-cotton settlement "Eódka", which in Polish means small boat, as Łódź means boat). It was set in the water-mill areas along the Jasien River. Finally, seven big water-mill areas for mechanical works were located on both sides of the river. This relatively small stream had a sufficient gradient and an appropriate volume of water all year around. Due to the slower technological development of Eastern Europe the energy generated by water was the most appropriate source of energy at that time and place. The first industrial settlement was soon covered with new facilities which were required by companies wanting to embark on cloth manufacturing and cotton fabric production (a mangling mill, a fulling mill, a starching mill, a bleaching mill). By around 1830, the number of in habitants in Lodz exceeded 5,000. Lodz definitely had entered the era of industrial civilization.

When it comes to wool production, Lodz was not able to catch up with better competitors such as Zgierz and Ozorków (before the November Uprising in 1830-1831, the former produced seven and the latter six times more wool fabrics than Lodz) or Kalisz, which had specialised in wool production since the 1820s. Technical progress and new organization of work was perfectly used in this industry. One of the first mechanized cotton mills in Poland was founded in 1825 by Krystian Wendisch in Lodz. In 1839, Ludwik Geyer opened mechanized cotton mills with steam engines and the first steam mill in the KP. The development of a new industry in Lodz - cotton spinning - attracted craftsmen who were searching for work after small woollen mills went bankrupt in several small villages nearby (Eęczyca, Turek and Poddębice). At the same time, the demand for cheaper products was rising among the poorer groups of society. In particular, the cotton manufacturers were able to meet this demand, as technical progress in cotton production was faster than in the other branches of the textile industry.

The first technical revolution in Lodz took place in the 1840s and 1850 s. New investors became active next to Geyer's Factory. They made a lot of investments and modernizations in their factories in order to keep up with the competition. Thanks to this, cotton spinning in Lodz was able to advance as a fully mechanized production department from the very beginning. Within only ten years, Geyer's local competitors were: Traugott Grohman, Dawid Lande, Jakub Peters, Karol Moess, and the most important of them all, Karol Scheibler. 
The speedup in cotton production came in two stages: the first thanks to the removal of the customs border with Russia in 1851, and the second after a resources crisis in the mid-1860s caused by the Civil War in the United States. As a result of the latter, Scheibler became the owner of the biggest spinning and weaving mills of cotton in the KP. By the 1870s, his factories (including the famous Priest's Mill - Księzy Mtyn) had been already equipped with 200,000 spindles and 3,500 looms (which constituted more than half of all looms in the $\mathrm{KP}^{17}$ ).

Other industrialists tried to follow Scheibler, but in the 1870s it was only Izrael Poznański who managed to match the scale of economic activity. Within seven years, by 1879 , he more than quadruplicated the number of machine shops, increasing their number to $860 .{ }^{18}$ Much like Scheibler, he had his own cotton plantations in the Caucasus and Central Asia, which made him independent of external suppliers of raw materials. It should be noted that the significance of water changed over the years. ${ }^{19}$ Steam machines were already in use in Lodz when the industrial district was founded. Water was nevertheless still important, but more for the washing, bleaching and dyeing processes.

Lodz took great advantage of the niche in the KP market (more broadly in the Eastern European one), specializing in the processing and manufacturing of cotton fabrics. But the Industrial Revolution also proceeded in the wool sector, though the process of mechanization lasted longer there, in spite of the fact that specialized machines were in use since the 1820s. Some of the first mechanical wool mills were installed in the plants of Jan Fryderyk Zachert at Zgierz, and in that of Fryderyk Schlösser at Ozorków. In the late 1860s, more than twenty mechanical spinning mills were at work in the district of Lodz. More quick progress could be observed in the industry in the 1870s when machine industry production, which supplied more than half of the total wool production of the KP, was popularized. In this respect, Lodz stood out again because it was there that Juliusz Heinzel built his factory with 850 looms. ${ }^{20}$

${ }^{17}$ In the 1880s almost a half of all spindles and 1/3 of all looms of the KP were still installed in Scheibler's factory.

18 J. Skodlarski, Zarys historii gospodarczej Polski, Warsaw, 2007, pp. 147-149; Miasta polskie w Tysiacleciu, vol. 2, ed. by M. Siuchniński, Wrocław-Warsaw, 1967, pp. 20-21.

${ }^{19}$ A Comparative Study of Łódź and Manchester..., p. 60.

${ }^{20}$ Heinzel, together with Juliusz Kunitzer, was the co-owner of the famous Widzew Manufactory founded in 1879. The name of the manufactory was of a purely marketing nature as it was a modern factory coming up against the ventures of Geyer, Scheibler and Poznański. 
The characteristic feature of the textile industry in the KP was the close geographical concentration. The position which the industrialists of Lodz built from the 1830s turned into an absolute hegemony in terms of the operating factories, new machines and equipment that were installed, the volume of output, and the number of workers. At the end of the $1870 \mathrm{~s}, 95 \%$ of the textile plants in the whole of the KP were located in the Lodz district; moreover, nearly $90 \%$ of fabric production and $73 \%$ of total employment was concentrated in this region. ${ }^{21}$ These numbers alone indicate the high level of productivity, since nearly $75 \%$ of employees were able to manufacture nine out of ten textile products produced in the KP. The factories of Scheibler and Poznański were the two largest plants in the KP and included numerous factory buildings, workers' apartments, manufacturers' palaces and other buildings.

The creation of public transport and intercity rail networks, which had a great economic importance, was a manifestation of technical progress. In the case of Lodz, it came with some problems, taking into consideration the dynamics of the city's development. In 1848, the city was granted access to the first goods and passenger station at Rokiciny. Of key importance, however, was when Lodz was connected in 1866 to the Warsaw-Vienna Railway line (operating since 1845) as it meant constant and direct contact with the rest of the country. The so-called Calisian Rail was launched in 1903, which provided a western connection to the rest of the KP. The creation of a modern public transportation network within the agglomeration was more difficult. The first electric railway line in the city was founded in 1898. A tram connection between Lodz, Pabianice and Zgierz was opened in the first decade of the twentieth century.

The speed of transformations is illustrated by the demographic changes. Between 1830 and 1837 the population of Lodz (permanent and floating) doubled to 10,000 , and again to 20,000 in 1846. By 1857 the number had doubled once more (to 40,000), although up to 1865 there was stagnation. Lodz's population exceeded 100,000 in 1883 while in 1877 there had been merely 50,000 residents. The city continued to develop demographically. In the last decade of the nineteenth century it already reached 200,000 inhabitants and some statistics indicate that in the 1900s the population exceeded 300,000. At the outbreak of World War I, more than half a million people ${ }^{22}$ lived there. So within a hundred

${ }_{21}$ W. Puś, Rozwój przemystu w Królestwie Polskim: 1870-1914, Łódź, 1997, p. 75.

${ }^{22}$ Akta miasta Łodzi [1471] 1794-1914 [1918]. Przewodnik po zespole, prep. M. Bandurka, Warsaw-Łódź, 1990, p. 11; Łódź. Dzieje miasta, vol. 1, ed. by R. Rosin, Warsaw-Łódź, 1980, p. 196. 
years, the population grew a thousandfold, from 500 to over 500,000. At the same time, the area of the city increased almost fivefold, as a result of incorporating surrounding villages and settlements, to nearly 6,000 ha (14,800 acres). ${ }^{23}$ It has to be admitted that, initially, the municipal authorities regulated the spatial expansion in a rational way, preventing wild land subdivision and spontaneous development. However, "the plans and intentions sufficient for a 15,000 city from 1840 turned out to be very harmful to the late nineteenth and early twentieth century Lodz that numbered thousands of factories and hundreds of thousands of residents". ${ }^{24}$ Needless to say, the village of Bałuty, which was incorporated into Lodz as late as 1915, numbered over 100,000 residents.

\section{Lodz Industrial District's economic domination}

The unique role of the Lodz Industrial District (henceforth: LID) in the KP in the last decades of the nineteenth century is confirmed by the statistical data indicating the number of plants, the volume of output, the scale of employment, and the level of mechanization. Although some of these indicators were subject to significant fluctuations, the advantage of the Lodz district may be easily noticed. At the end of the $1870 \mathrm{~s}$ and in the $1900 \mathrm{~s}$, the number of the LID plants amounted to $25 \%$ of all the works in the KP, and at the apogee in 1904, to nearly $33 \%{ }^{25}$ Taking into account the share of the total KP production, we can even speak about the LID's dominance of manufacturing. From the 1870 s to the outbreak of WWI, this share was always higher than $1 / 3$, but at the turn of the twentieth century (as at the end of the 1870s), it even exceeded $40 \%{ }^{26}$

When it comes to the number of employees, the district of Lodz had a slightly smaller advantage over the other industrialized regions in the $\mathrm{KP}$, though its leadership throughout the period of forty years before WWI remained unthreatened. Considering Lodz's share in the KP's industrial output, it indicates the higher labour productivity. The number of LID workers varied from $25 \%$ (the 1870 s and 1880 s) to over $33 \%$ (from the 1890s to the outbreak of the war) of all the employees in the KP. The data on the growth of employment in Scheibler's plants alone

${ }^{23} 550$ lat miasta Łodzi: 150 lat Łodzi przemysłowej, ed. by S. Kwiatkowski, Łódź, 1973, p. 10.

${ }^{24}$ Eódż. Dzieje miasta..., p. 191.

${ }_{25}$ W. Puś, Rozwój przemystu..., pp. 52-53.

${ }^{26}$ Ibid. 
are also evidence of the scale of this advantage, and, at the same time, of the dynamics of the changes. In 1861, his factory employed more than 150 workers, ten years later over 1000, and in 1881 the number increased to nearly 5,500. In total, in the mid-1880s, nearly 800 factories and industrial plants operated in Lodz employing 20,000 people. By the early twentieth century, their number had grown to nearly $60,000 .{ }^{27} \mathrm{In}$ terms of employment, Lodz prevailed whatever the level of the country's administration we take (in the guberniya (governorate), the voivodeship (province), and the entire KP). In the Piotrków Guberniya, within the boundaries of which Lodz was located, about 50\% of the workers found employment right in Lodz. In turn, over 90\% of the Lodz labourers worked in the textile industry. The scale of this specialization coincided with the outcomes of the production volume - in 1900, $87 \%$ of the whole city's manufacturing was connected with the textile industry. ${ }^{28}$

Another important criterion indicating the high level of Lodz's industrial development and technological advancement is the district's share in the total power of machinery and electric motors, which is expressed in horsepower (henceforth: HP). In this respect, the LID was in second place in the KP (following the Sosnowiec-Częstochowa District) but its share significantly increased from over $16.5 \%$ in 1879 to $31 \%$ in 1913. At that time, the rate of industrial mechanization commonly expressed in terms of HP per worker increased from 0.11 to $0.91 .^{29}$ However, the mechanization growth rate (over eightfold) during those 34 years was the highest in the whole Kingdom.

The advantage of the LID in so many diverse aspects of industrialisation was not discounted by commercial activities or the development of financial institutions. The LID's commodities were basically released only in the eastern market - primarily in the western and southern parts of the Russian Empire. The growth of exports in the late nineteenth and early twentieth centuries could be seen in exports to Ukraine (including the Crimean Peninsula). The market of Lithuania, Belarus and the district of the Volga Region, the Ural Mountains, Kuban and the Caucasus were stable. Products from Lodz sold poorly in Siberia, Central Asia and the Far East, while conquering the Western European market was hardly possible because of the high custom duties separating the Russian Empire from the rest of Europe. It was accompanied by the tendency to gradually diminish the level of the institutional barriers

${ }^{27}$ Łódź. Dzieje miasta..., p. 263.

${ }_{28}$ Miasta polskie w Tysiacleciu..., p. 21.

${ }^{29}$ W. Puś, Rozwój przemystu..., p. 55. 
to foreign trade between Western European countries initiated by the Cobden-Chevalier treaty signed by France and Great Britain in 1860. That example was followed by other European countries, which eventually led to the establishment of a system of bilateral trade agreements with the most favoured nation clause. As a result, the whole of Europe, with the exception of Russia, was covered by those preferential conditions of trade, making it similar to a free trade area. But entrance to this market by entities coming from outside the area was extremely difficult, as they would have needed to be much more competitive than the European firms. Nevertheless, it was shortly before the outbreak of WWI that an attempt to gain new areas for export was made, including Iran, Mongolia and the Balkans. These plans, however, were interrupted by the global conflict. The location of warehouses, subsidiaries, and agencies which appeared not only within the area of the KP in Lodz and Warsaw, but also in Saint Petersburg, Kharkiv, Odessa, Berdychiv, Riga, and Rostov-on-Don ${ }^{30}$ was a testimony to the scale of the Lodz region's entrepreneurial activity.

The example of Lodz's history not only perfectly illustrates the origins and development of capitalism in Polish lands, but it also gives an opportunity to directly contrast the situation with the Industrial Revolution as a whole. The process of transitioning from manufactories to factories was extremely fast; it took about thirty-forty years, beginning in the 1830s and lasting until the mid-1860s. From the 1870s on, we can talk about the dynamic development of factories with great technical innovations, intra-industry specialization, production concentration in the industry and space, targeting trade, improvements in the organization of work, or the mass exploitation of the labour force.

The changes in the LID were even more rapid than in the leading area of the textile industry in the world - Manchester. The tangible results speak volumes about the revolution. With only data from the $\mathrm{KP}$ at hand, we know that the consumption of raw cotton in kg per person increased fifteen-fold (from half a kilo to 7.5 kilos) between 1870 and 1913. The growth indicator exceeded the achievements in the most industrialized countries, including Great Britain, the United States, Germany, and France. On the other hand, the second indicator showed a bigger distance between the Polish lands and the homeland of the Industrial Revolution. Before the outbreak of the First World War, cotton consumption was threefold higher than in Russia (2.5 kilos per person). It was a bit higher than in France (less than 7 kilos), and a bit

\footnotetext{
${ }^{30}$ Łódż. Dzieje miasta..., p. 273.
} 
higher than in Germany (7.7 kilos). It was almost a half less than in the US (over 14 kilos), and exceptionally lower than in England (24 kilos). ${ }^{31}$ All in all, the textile industry was the only branch of industry in the KP which managed to catch up with the European level. It was achieved thanks to the development of the LID. ${ }^{32}$

\section{The specific case study: Karol Anstadt's brewery in Lodz}

The advantageous geographical location of the city and especially the access to water provided favourable conditions for carrying out some specific forms of economic activity. Anstadt's brewery is an interesting example illustrating this relationship. Brewing, unlike textiles, was not an industry supported by the authorities of the KP. This approach corresponded with the poor characteristics of the city's food production market. Due to the small number of food producers, food prices were very high. Breweries were treated as a craft with low profits and with no major development prospects. In a sense, it was a waste of the potential created by the influx of German settlers who not only possessed capital resources but who also had the technological know-how. Through their habits and culinary traditions, they could stimulate (also indirectly) the demand for food and drink.

Until the late 1870s, brewing was still seen as a craft, not an industry. In 1846, Lodz breweries produced approx. 6000 hectolitres (hl) of beer. The average consumption per capita per year was ca. 30 litres. ${ }^{33}$ From the description of Lodz provided by Oskar Flatt, it is known that by 1853 there were only two brewers in the city. Six years later there were still two breweries competing in the local market: the brick one owned by Konstadt and Dobraniecki (purchased from Henrietta Saenger) and the wooden one of Bauch (formerly owned by Bittdorf). ${ }^{34}$

31 W. Puś, Rozwój przemystu..., pp. 169-170.

32 Searching for important institutional factors decisive for Lodz's long-term growth in the 19th century, we should also mention the role of immigrants - Germans and especially the Jewish minority. See more: id., Żydzi w Eodzi w latach zaborów 1793-1914, Łódź, 2003; S. Pytlas, Łódzka burżuazja przemysłowa, Łódź, 1994, p. 43, 52. See also: id., "Skład narodowościowy przemysłowców łódzkich do 1914 r.", in: Dzieje Żydów w Eodzi 1820-1944, ed. by W. Puś, S. Liszewski, Łódź, 1991, pp. 55-78.

${ }_{33}$ O. Flatt, Opis miasta Łodzi pod względem historycznym, statystycznym i przemysłowym, Warsaw, 1853, p. 52.

34 The first brewery open in Lodz after 1820 was the Karol Saenger brewery. Later, the breweries of Andrzej Wagner (1830) and Antoni Bittodorf (1841-1844) were 
Their total production amounted to about $11,000 \mathrm{hl}$. In total, the two plants employed 18 workers. ${ }^{35}$ A twofold increase in production over 13 years confirmed the increasing profitability of the business. The consumption per capita of 27 litres per year set Lodz above the average of the KP. The economic slowdown of 1861-1864 due to the so-called cotton famine and the Polish January Uprising (1863) organised to regain independence from Russia led to stagnation in the brewery market. There was a drop in beer consumption in the city such that the Dobraniecki and Konstadt plant went bankrupt. On the other hand, one brewery was not sufficient to meet the needs of the city's inhabitants. Lodz beer was mainly bought by labourers and craftsmen (they accounted for approx. $75 \%$ of the population of Lodz). The intelligentsia, professionals, and wealthy citizens often chose wine or beer from Czech and German breweries. As a result, the brewery produced lowcost beer of poor quality and with a high alcohol content. In 1868, the value of production in this industry in Lodz amounted to 100,000 roubles, while the mills and bakeries produced more than 1 million roubles.

The largest and most important of the Lodz breweries were the factories of the Anstadts. Karol Gottlob Anstadt came to Lodz in the 1830s, dealing initially with calico printing. Business was booming until the end of the 1860s when the entrepreneur gave up the former activity and his invested capital in the new field. The Lodz beer market was relatively easy due to the lack of strong competitors (one obsolete brewery). Furthermore, the abolition of the consumption tax in 1866 gave hope for extraordinary gains in the field of beer production. The pressure exerted by the breweries and suburban taverns which had sold untaxed, cheaper beer reduced significantly after the abolition. Anstadt took advantage of the opportunities and applied for permission to build a brewery in Średnia Street (currently Pomorska Street) just next to the Łódka River. Other famous entrepreneurs such as Abram Prussak, Robert Biedermann, Israel Poznanski, and the brothers Herman and Richard Gehlig, who took over the Bauch brewery from Adolf Gehlig, also located their companies along the Łódka.

The proximity of the water helped to save a lot of time and money regarding how it was obtained and especially regarding transport. As Miroslaw Jaskulski noted "after the application of new brewing

built. With the passing of time, the owners of those enterprises changed; S. Rytych, Piwowarstwo tódzkie do roku 1864, Łódź, 2005, pp. 61-81.

${ }_{35}$ M.J. Szymański, Browary Łodzi i regionu. Historia i współczesność, Łódź, 2011, p. 25 . 
technology, water was kept in the form of ice and utilized to lower the temperature of the finished product". ${ }^{36}$ The alternative was to draw water from wells and store transported water in uncovered tanks both expensive and spatially inefficient (the method was applied in the Lorentz brothers' brewery in Widzewska Street - currently Kilińskiego Street). Another solution was to construct a water channel. This option was chosen by Ludwik Anstadt in his brewery at Radogoszcz. The most difficult situation was found in plants that could not benefit from any of the mentioned solutions. They had to be stocked up with artificial ice produced by chillers. For example, the Gehlig brothers' brewery had a factory producing artificial ice which it also sold to other breweries. The importance of being located near a source of water for the brewing industry began to decline as late as the early nineteenth century, with the introduction of the ammonia system of beer cooling.

By sheer coincidence, the first industrial plant for brewing in Lodz was built near the site where the court brewery had operated for several years in the period of agricultural Lodz. ${ }^{37}$ In 1867, the first industrial brewery building - the brew house - was finished. After Karol Anstadt's death in 1874, the ownership of the company was taken over by the sons of the founder, Ludwik and Zenon. The brewery expanded territorially through other parcels of land acquired by the Anstadts. A water reservoir was dug and later linked with the channel to the Łódka. It served as a source of ice in winter. Plans for further buildings were drawn up: a smithy, a boiler room, and refrigerated storage. A new steam engine with two boilers was installed in around 1880. The project was a great success, even though competition had entered the market. There were four breweries (the Anstadts', the Gehligs', the Lorentzs', and Milsch's) with a total production of 180,000 roubles and employing 46 workers in $1880 .^{38}$ Aside from the brewing business, Ludwik Anstadt was also the founder of a park (1881) in the Eódka valley (just next to the brewery). The park was named Helenów after his wife Helena. It was soon a prestigious place, and being seen there was a sign of belonging to the upper class. The main attractions were ponds and fountains. For years Helenów enjoyed the status of being the best kept and most beautiful park in Lodz.

${ }^{36}$ M. Jaskulski, "Browar Karola Anstadta w Łodzi (1867-1914)", Varia (Muzeum Historii Miasta Łodzi), 1983, no. 1, p. 31.

37 Ibid.

38 J.G. Bloch, Przemyst fabryczny Królestwa Polskiego w okresie dziesięcioletnim od 1871 do 1880 r. z uwzględnieniem jego stanu poprzedniego, Warsaw, 1884, p. 121. 
Some legal issues relating to the ownership structure of the plant were clarified. The Karol Anstadt Successor Company was established. After his death, Karol's wife, Teresa, and their children transformed the company into a joint stock company (the Steam Brewery of K. Anstadt Successor's Stock Company ${ }^{39}$ ). Further investments in brewery machinery resulted in increased capacity of the enterprise. In 1900, Ludwik Anstadt built his own brewery in Sędziowska Street (current name). Zenon Anstadt, in turn, took over the private brewery at Zduńska Wola (50 km from Lodz). It was a good time for owners of breweries. At the end of the nineteenth century, the highest beer consumption per person was recorded in Warsaw province (19 litres) and Piotrków province (Lodz was part of the province - 14 litres). While in the remaining part of the country it was only $3-6$ litres.

Profit was reaped not only from the sales of beer. Part of the revenues came from the sales of used malt and yeast sediment. The fiscal policy of Russia exerted a profound impact on Anstadt's brewery. The tsar drew huge income from the distillery and inhibited the development of brewing. A manifestation of this policy was an increase of the tax burden. The level of taxation on beer was raised by $50 \%$ in 1892 . Despite this, the brewery brought in as much as 48,000 roubles profit in $1896 .{ }^{40}$ The scale of the tax burden is highlighted by the fact that in 1902 the excise tax accounted for a quarter of the revenue from the sale of beer, while the wages of workers just $1 / 6{ }^{41}$

Anstadt's Brewery, as it was then called, offered home delivery of beer. The company had beer stores in many cities, for instance in Vilnius and Warsaw. It had its own wagons on the Warsaw-Vienna and Kalisz rail connections. The basic form of distribution was the bottle, rarely a barrel. Initially, bottles were corked, like wine. Later, more convenient reusable closures were applied. It is possible that this facility boosted sales of bottled beer. In 1900, a new steam engine with twice the capacity of the previous one was purchased. The company still maintained financial liquidity, although the level of employment and the profits fluctuated depending on sales volumes and prices of beer on the market. ${ }^{42}$ In 1910 , the company embarked on the production of carbonic acid, which quickly generated extra revenues. The launch of this production line probably resulted in the increase of employment

${ }^{39}$ The name "Karol Anstadt's brewery" will be used in the article.

${ }^{40}$ M.J. Szymański, op. cit., p. 51.

${ }^{41}$ M. Jaskulski, op. cit., p. 37.

${ }^{42}$ For example, the employment in Karol Anstadt's brewery fell by 40\%; M.J. Szymański, op. cit., p. 53. 
to 119 workers in 1914. During World War I, part of the assets of the brewery was taken by the Germans. For the first time in its history, the brewery did not make a profit.

The success of Anstadt's brewery (under different names) is an example of the successful synergy of a good idea, effective management and the skilful use of the geographical factor. Lowering the cost of production due to convenient access to water at the beginning of the project enabled the rapid development of the brewery, supported the expansion on the local market, and ultimately resulted in economic success. From the end of the nineteenth century, the brewery in Średnia Street was not only the largest producer of beer in Lodz, but also the largest plant in the local food industry.

\section{Short conclusions; further studies}

Among decisive factors that influenced the transformation of Lodz from an agricultural village to an industrial city we should point to its geographical location and environmental factors. In the present study we tried to examine their role but we could not omit the institutional changes. The geography itself was of course an insufficient factor, but it was not until the nineteenth century that two factors - namely natural resources and institutions - started to play a crucial role. Environmental factors were essential for "taking-off" of Lodz, although formally the industrial origins of Lodz lie in the decision taken in 1820 to establish a settlement of clothiers there. We claim that political choices are strictly correlated with environmental factors. The interdependence between the location of the textile industry and the water supply used as a driving force was the reason for the decision to establish the early industrial districts along river valleys (the spatial concentration of industrial areas in river valleys). This stage was mainly connected with the cotton and linen industry. Furthermore, as the example of Andstadt's brewery illustrates, the access to water was also utilized in the food industry. This stage of the industrialization process lasted until the 1860s. In the second stage, which lasted until 1914, the development was mainly due to the textile industry and steam engine technology. In this period, the prosperity of city was strengthened considerably by the railway connection that linked the centre of Lodz with Warsaw. It apparently eased and sped up the expansion of the industrial district beyond the river valleys.

The geographical advantages of Lodz provided by its favourable location and access to water were fully utilized. "Fully", in as far as it 
was possible for part of a non-sovereign state. The development was interrupted by WWI which resulted in the re-emergence of the Polish state and new opportunities for the development of Lodz. To conclude, we support the opinion that geography highly mattered in the development of Lodz. Anyway, this factor should be strictly analysed with institutional framework. ${ }^{43}$ We also have to add one more comment to Acemoglu and Robinson conclusion: ${ }^{44}$ that geographical factors may have been important not only in times of the dominance of agriculture, but also in the era of dynamic industrialisation.

\section{Bibliography}

Acemoglu D., Introduction to Modern Economic Growth, Princeton-Oxford, 2009.

Acemoglu D., Johnson S., Robinson J.A., "Institutions as the fundamental cause of long-run growth", in: Handbook of Economic Growth, vol. 1A, ed. by Ph. Aghion, S. Durlauf, North Holland, 2005.

Acemoglu D., Robinson J.A., "The role of institutions in growth and development", in: The World Bank Commission on Growth and Development, Working Paper no. 10, Washington, 2008.

Acemoglu D., Robinson J.A., Why Nations Fail. The Origins of Power, Prosperity and Poverty, New York, 2012.

Allen R.C., Global Economic History. A Very Short Introduction, New York, 2011.

Arthur B., "Competing technologies, increasing returns, and lock-in by historical small events", Economic Journal, 1989, no. 1, pp. 116-131.

Beattie A., False Economy. A Surprising Economic History of the World, New York, 2009.

Bloch J.G., Przemyst fabryczny Królestwa Polskiego w okresie dziesięcioletnim od 1871 do 1880 r. z uwzględnieniem jego stanu poprzedniego, Warsaw, 1884.

Cameron R., A Concise Economic History of the World. From Palaeolithic Times to the Present, Oxford, 1993.

Clark G., A Farewell to Alms. A Brief Economic History of the World, Princeton-Oxford, 2007.

Colinvaux P., The Fates of Nations. A Biological Theory of History, New York, 1980.

A Comparative Study of Łódź and Manchester. Geographies of European Cities in Transition, ed. by S. Liszewski, C. Young, Łódź, 1997.

${ }^{43}$ We try to include these new aspects in further research. We are just preparing the paper entitled: "Geography and Institutions instead of Geography versus Institutions".

${ }^{44}$ D. Acemoglu, J. Robinson, Why Nations Fail..., pp. 48-56. 
David P., "Clio and the economics of QWERTY", American Economic Review, 75, 1985, no. 2, pp. 332-337.

Diamond J., Guns, Germs and Steel. The Fates of Human Societies, New York, 1997.

Diamond J., Collapse. How Societies Choose to Fail or Succeed, New York, 2005.

Dylik J., Rozwój osadnictwa w okolicach Łodzi, Łódź, 1948 (Acta Geographica Lodziensis, 2).

Dzionek-Kozłowska J., Matera R., "New institutional economics' perspective on wealth and poverty of nations. Concise review and general remarks on Acemoglu and Robinson's concept", Scientific Annals of the 'Alexandru Ioan Cuza' University of Iasi. Economic Sciences, 2015, no. 62 (SI), pp. 11-18.

Dzionek-Kozłowska J., Matera R., "Institutions without culture. A critique of Acemoglu and Robinson's theory of economic development", Lodz Economic Working Papers, 2016, no. 9, pp. 1-15.

Dzionek-Kozłowska J., Matera R., "O poszukiwaniu przyczyn bogactwa i nędzy narodów w teorii Darona Acemoglu i Jamesa A. Robinsona”, Gospodarka Narodowa, 27, 2016, no. 5 (285), pp. 5-26.

Flatt O., Opis miasta Łodzi pod względem historycznym, statystycznym i przemysłowym, Warsaw, 1853.

Lal D., Reviving the Invisible Hand. The Case for Classical Liberalism in the Twenty-First Century, New Jersey, 2006.

Landes D., The Wealth and Poverty of Nations. Why Some Are So Rich and Some So Poor, New York, 1998.

Maddison A., "Explaining the economic performance of nations 1820-1989", in: Convergence of Productivity, ed. by W. Baumol, R. Nelson, E. Wolff, Oxford, 1993, pp. 20-61.

Maddison A., The World Economy. A Millennial Perspective, Paris, 2001.

Maddison A., Contours of the World Economy 1-2030 AD. Essays in Macro-Economic History, Oxford, 2007.

Marshall A., Principles of Economics, vol. 2, London, 1961, App. A, par. 10.

Matera R., "Studia nad bogactwem i ubóstwem narodów na przełomie mileniów - wkład Darona Acemoglu i Jamesa A. Robinsona", Ruch Prawniczy, Ekonomiczny i Socjologiczny, 76, 2014, no. 1, pp. 269-282.

North D.C., Structure and Change in Economic History, New York, 1981.

North D.C., Institutions, Institutional Change and Economic Performance, Cambridge, 1990.

North D.C., Understanding the Process of Economic Change, New Jersey, 2005. Olson M., The Rise and Decline of Nations. Economic Growth, Stagflation, and Social Rigidities, New Haven-London, 1982.

Puś W., "Skład narodowościowy przemysłowców łódzkich do 1914 r.", in: Dzieje Żydów w Łodzi 1820-1944, ed. by W. Puś, S. Liszewski, Łódź, 1991, pp. 55-78.

Puś W., Rozwój przemystu w Królestwie Polskim: 1870-1914, Łódź, 1997.

Pytlas S., Łódzka burżuazja przemysłowa, Łódź, 1994. 
Robinson J.A., "Economic development and democracy", Annual Review of Political Science, 2006, no. 9, pp. 503-522.

Rytch S., Piwowarstwo łódzkie do roku 1864, Łódź, 2005.

Sachs J., The End of Poverty. The Economic Possibilities for Our Time, New York, 2005.

Sen A.K., Poverty and Famines. An Essay on Entitlement and Deprivation, Oxford, 1982.

Sen A.K., Development as Freedom, New York, 1999.

Sen A.K., The Price of Inequality. How Today's Divided Society Endangers

Our Future, New York, 2012.

Sokołowicz M., Rozwój terytorialny w świetle dorobku ekonomii instytucjonalnej. Przestrzeń, bliskość, instytucje, Łódź, 2015.

Stiglitz J.E., Globalization and its Discontents, New York, 2002.

Szymański M.J., Browary Łodzi i regionu. Historia i wspótczesność, Łódź, 2011.

Joanna Dzionek-Kozłowska, Kamil Kowalski, Rafał Matera

Geography Matters. Environmental Factors that Affected the "Take-Off" of Lodz

(Summary)

The object of the paper is to analyse the geographical and institutional factors that played a key role in the development of Lodz Industrial District, Lodz, and brewery in Lodz. We formulate the hypothesis that, in the case of both Lodz, and the Lodz Industrial District the long-term development would not be possible without a few environmental factors which supported to make good decisions and to impose institutional stabilization of the city. In the last part of the article we focus on Karol Anstadt's brewery which was direct good example of interaction between geographical and institutional connections.

Joanna Dzionek-Kozłowska - dr, adiunkt w Katedrze Historii Myśli Ekonomicznej i Historii Gospodarczej Instytutu Ekonomii (Wydział Ekonomiczno-Socjologiczny) Uniwersytetu Łódzkiego. Zainteresowania badawcze: historia myśli ekonomicznej, filozofia nauki, etyczne aspekty działalności gospodarczej. Redaktor naczelny czasopisma „Annales. Etyka w Życiu Gospodarczym”. Wybrane publikacje: System ekonomiczno-spoteczny Alfreda Marshalla, Warszawa 2007; Ethics in Economic Thought. Selected Issues and Various Perspectives, Łódź-Kraków 2015 (wraz z R. Matera).

Joanna Dzionek-Kozłowska - PhD, lecturer at the Department of History of Economic Thought and Economic History of the Faculty of Econom- 
ics and Sociology, University of Lodz. Her research interests lie in: history of economic thought, philosophy of science, ethical aspects of economic activity. She is editor-in-chief of the scientific journal Annales. Etyka $w \dot{z} y c i u$ gospodarczym (Annales. Ethics in Economic Life). Among her publications are: System ekonomiczno-społeczny Alfreda Marshalla, Warsaw, 2007; Ethics in Economic Thought. Selected Issues and Various Perspectives, Łódź-Kraków, 2015 (together with R. Matera).

E-mail: joanna.dzionek@uni.lodz.pl.

Kamil Kowalski - dr, adiunkt w Katedrze Historii Myśli Ekonomicznej i Historii Gospodarczej Instytutu Ekonomii (Wydział Ekonomiczno-Socjologiczny) Uniwersytetu Łódzkiego. Zainteresowania badawcze: historia USA po II wojnie światowej, międzynarodowa ekonomia polityczna, historia Łodzi. Wybrane publikacje: Plan Marshalla. Uwarunkowania i skutki gospodarczo-polityczne, Łódź 2014; Rola Żydów w rozwoju gospodarczym ziemi łódzkiej. Wybrane zagadnienia, Łódź 2014 (wraz z J. Skodlarskim, R. Matera, K. Lutek, A. Pieczewskim).

Kamil Kowalski - PhD, lecturer at the Department of History of Economic Thought and Economic History of the Faculty of Economics and Sociology, University of Lodz. His scholarly interests include: history of the U.S. after World War II, international political economy, history of Lodz. His selected publications: Plan Marshalla. Uwarunkowania i skutki gospodarczo-polityczne, Łódź, 2014; Rola Żydów w rozwoju gospodarczym ziemi łódzkiej. Wybrane zagadnienia, Łódź, 2014 (together with J. Skodlarski, R. Matera, K. Lutek, A. Pieczewski).

E-mail: kamil.kowalski@uni.lodz.pl.

Rafał Matera - dr hab. prof. nadzw. w Katedrze Historii Myśli Ekonomicznej i Historii Gospodarczej Instytutu Ekonomii (Wydział Ekonomiczno-Socjologiczny) Uniwersytetu Łódzkiego. Członek Zarządu Polskiego Towarzystwa Historii Gospodarczej. Zainteresowania badawcze: historia gospodarcza, historia myśli ekonomicznej, relacje transatlantyckie. Wybrane publikacje: Integracja ekonomiczna krajów nordyckich, Torun 2001; Gospodarka światowa. Geneza i rozwój, Warszawa 2004 (wraz z J. Skodlarskim); Stany Zjednoczone $i$ Europa. Stosunki polityczne i gospodarcze 1776-2004, Warszawa 2007 (wraz z P. Matera); G8 jako instytucja gospodarki światowej, Łódź 2009; Ethics in Economic Thought. Selected Issues and Various Perspectives, Łódź-Kraków 2015 (wraz z J. Dzionek-Kozłowska).

Rafał Matera - DSc, associate professor of the Department of History of Economic Thought and Economic History of the Faculty of Economics and Sociology, University of Lodz. Member of the Board of Directors of the Polish 
Association of Economic History. His research interest focuses on: economic history, history of economic thought, transatlantic relations. Among his numerous publications are: Integracja ekonomiczna krajów nordyckich, Torun, 2001; Gospodarka światowa. Geneza i rozwój, Warsaw, 2004 (together with J. Skodlarski); Stany Zjednoczone i Europa. Stosunki polityczne i gospodarcze 1776-2004, Warsaw, 2007 (together with P. Matera); G8 jako instytucja gospodarki światowej, Łódź, 2009; Ethics in Economic Thought. Selected Issues and Various Perspectives, Łódź-Kraków, 2015 (together with J. Dzionek-Kozłowska).

E-mail: rafal.matera@uni.lodz.pl. 